\title{
Ecology of antifouling resistance in the bladder wrack Fucus vesiculosus: patterns of microfouling and antimicrobial protection
}

\author{
M. Wahl ${ }^{1, *}$, L. Shahnaz ${ }^{1,2}$, S. Dobretsov ${ }^{1,3}$, M. Saha ${ }^{1}$, F. Symanowski ${ }^{1}$, K. David ${ }^{1}$, \\ T. Lachnit ${ }^{1}$, M. Vasel $^{1}$, F. Weinberger ${ }^{1}$ \\ ${ }^{1}$ Leibniz Institute of Marine Sciences, IFM-GEOMAR, Duesternbrookerweg 20, 24105 Kiel, Germany \\ ${ }^{2}$ Present address: Department of Botany, University of Karachi, Karachi, Pakistan \\ ${ }^{3}$ Present address: Department of Marine Science and Fisheries, Sultan Qaboos University, Muscat, Oman
}

\begin{abstract}
The impact of moderate environmental stress may be modulated by stress-induced shifts of biotic interactions such as host-epibiont relationships. We studied the stress regime in shallow Western Baltic habitats, the variability of fouling at different temporal and spatial scales, and whether common stressors - low light, high temperature and grazing - affect the abundance and composition of the biofilm on a regionally important macroalga, the bladder wrack Fucus vesiculosus. We further explored the alga's capacity to chemically modulate the recruitment of microfoulers and analyzed whether this ability is impacted by stress. In laboratory, mesocosm and field experiments, fouling pressure and epibiotic cover on the alga varied strongly with changing environmental conditions such as temperature, irradiance, depth and grazing. The expectation that abiotic stress affects the fouling-modulating ability of the alga and thus indirectly produces the observed variability of epibiosis was not generally confirmed. Indeed, while the strength of chemical antifouling resistance varied seasonally, with a maximum in winter-spring and a minimum in late summer, this could not be related to temporal patterns of environmental stress, fouling pressure, or growth of $F$. vesiculosus. Only the seasonal variation in reproduction seemed to be in phase with antifouling activity. Controlled experiments confirmed that resistance strength was not affected by temperature or grazing, and only moderately by light. We conclude that the fouling modulation ability of $F$. vesiculosus may suffer from light reduction (e.g. by eutrophication effects), but is not sensitive to predicted warming or enhanced grazing.
\end{abstract}

KEY WORDS: Marine algae - Stress - Epibiosis - Fouling modulation - Interacting stressors · Fucus vesiculosus

Resale or republication not permitted without written consent of the publisher

\section{INTRODUCTION}

Marine organisms are exposed to an almost unceasing fouling pressure, which is spatially and seasonally variable in intensity and species composition. Typically, $1 \mathrm{ml}$ of seawater contains $10^{1}$ to $10^{2}$ larvae and spores, $10^{3}$ fungal cells, $10^{6}$ bacteria and $10^{7}$ viruses (reviewed in Harder 2008). Most of these require a solid-liquid interface for best performance and development. In most shallow marine habitats, non-defended surfaces are covered to $100 \%$ and more within a few months (e.g. Richmond \& Seed 1991, Railkin 2004). Micro- and macrofouling may profoundly change the optical, mechanical, physical and chemical properties of the body surface of marine organisms and, consequently, all interactions linked in some way to these properties. Besides the direct effects on the host, epibiotic communities may affect the host's access to resources (e.g. Harder 2008), its susceptibility to fouling (Holmstrom \& Kjelleberg 1999, Dobretsov 2008) or its susceptibility to 
grazing effects (e.g. Enderlein et al. 2003, Korpinen et al. 2007a). Since most fouling effects are not neutral (Wahl 2008), many marine organisms have developed mechanisms to modulate the colonization of their body surfaces to some extent (e.g. Paul \& Ritson-Williams 2008). Mechanical and chemical adaptations have been described; these frequently form multiple systems (Wahl et al. 1998).

If the deployment of resistance traits incurs energy costs which compete with other metabolic budgets (e.g. Harvell 1998) and if energy is limiting (Jormalainen \& Ramsay 2009), then producing resistance traits only when needed should be selectively favoured (Tollrian \& Harvell 1999). While the bladder wrack Fucus vesiculosus is capable of inducing or reducing its chemical resistance to mesograzers according to grazing pressure (Rohde \& Wahl 2008a), no similar information is available for antifouling resistance of this or any other algal species. We do not know whether, nor do we know how antifeeding and antifouling resistance interact within the producer alga. They could be independent of each other, antagonistic if competing for limiting resources or linked by shared biosynthetic pathways.

Environmental stress such as extreme temperature or low light may impose additional energy costs for protective or repair mechanisms (e.g. Dethier et al. 2005). This could jeopardize the production of resistance, in particular when the defenses are not constitutive but regulated. Abiotic and biotic stressors (e.g. grazing) may interact, but we know little about multiple stressor action and interactive feedback (Vinebrooke et al. 2004, Christensen et al. 2006).

In the Western Baltic, the bladder wrack Fucus vesiculosus occurs mainly between mean sea surface level (MSSL) and $3 \mathrm{~m}$ depth. A variety of abiotic stresses are common in this habitat, some with a tendency to increase in the course of climate change. Candidates with a high potential for impact on $F$. vesiculosus in this habitat are mechanical stress through wave action or ice, extreme temperatures, high and low light, intense grazing and acidified conditions (e.g. Pavia et al. 1997, Korpinen et al. 2007a, Jormalainen et al. 2008, Dethier \& Williams 2009, Krause-Jensen et al. 2009). According to most climate change scenarios, in the Western Baltic, stress caused by high temperature, high nutrient load, fluctuating salinity, low light and, more indirectly related to climate change, epibiosis and mesograzing will increase, while ice scouring will decrease (IPCC 2007, BACC Author Team 2008). F. vesiculosus has already retreated from the deeper parts of its former distribution during past decades (Vogt \& Schramm 1991), presumably due to a combined action of the stressors eutrophication, epibiosis and grazing (Rohde et al. 2008, Jormalainen \& Ramsay 2009, Krause-Jensen et al. 2009).
Abiotic as well as biotic stress may be modulated by epibiosis (Wahl 2008). Fouled algae may be more susceptible to drag or shading (e.g. Rohde et al. 2008), but less sensitive to light inhibition or damaging effects of UV radiation at shallow depths (e.g. Penhale 1977, Biermann et al. 1992). Low nutrient stress can be enhanced by epiphytes competing for the same resources, but scarce micronutrients can also be provided by biofilm components (Ericcson \& Lewis 1953, Fries 1982, Matsuo et al. 2005). Epibionts may attract or repel potential consumers of their host and thus modulate this biotic stressor (e.g. Wahl \& Hay 1995, Jormalainen et al. 2008).

We recently described that the composition of bacterial biofilms on Fucus vesiculosus, usually the first phase of colonization, is quite distinct from the bacterial colonizer pool in the seawater and the biofilms of neighbouring algae or non-living substrata (Lachnit et al. 2009). On the other hand, the composition of the bacterial biofilm on $F$. vesiculosus varies with season and between conspecific hosts to some extent (Lachnit et al. 2010). This heterogeneity probably reflects seasonal variability of fouling plus variability of surface properties of the hosts. The latter could be caused by fluctuations of the algal metabolites modulating microfouling, as shown for other species (Hellio et al. 2004).

To shed some light onto these questions we proceeded in 4 steps: (1) characterization of the abiotic regime in a typical Fucus vesiculosus habitat of the Western Baltic, (2) assessment of the variability in microfouling pressure with temperature and depth, (3) characterization of the microfouling on $F$. vesiculosus and (4) investigation of the ability of $F$. vesiculosus to modulate microfouling in different stress scenarios. We present the findings from a series of experiments in this sequence. Due to the complexity of the matter, the resulting picture is far from complete. Our main intention is to explore the ecological potential of the feedback loops between abiotic stressors and biotic interactions, and hopefully prompt further research on the topic of biotic interactions modulating environmental stress.

\section{MATERIALS AND METHODS}

Plant material. Unless mentioned otherwise, Fucus vesiculosus plants were freshly collected from the littoral zone of Kiel Fjord (54 $26^{\prime} \mathrm{N}, 10^{\circ} 11^{\prime} \mathrm{E}$ ) in individually sealed zip-lock bags. During transportation to the laboratory, algal thalli were kept in a cool box.

Gradients and fluctuations in the abiotic underwater regime. The light and temperature regime at different depths was assessed at 10 min intervals by a chain of loggers $\left(\mathrm{HOBO}{ }^{\circledR}\right.$, Onset Computer Corpora- 
tion) exposed above water $(+5 \mathrm{~m})$ and close to the sea floor at $0.5 \mathrm{~m}$ steps between 0 and $5 \mathrm{~m}$ depth between May 2008 and March 2009 at the sampling site. Salinity, $\mathrm{pH}$ and $\mathrm{pCO}_{2}$ were measured every $2 \mathrm{wk}$ between May and September 2009 in Kiel Fjord using a Sea \& Sun Technology multiprobe.

Reduction of light transmission by biofilms at different temperatures and depths. To assess how one aspect of season, i.e. temperature, affects the density and, consequently, the shading effect of biofilms for a given colonizer pool, transparent Plexiglas discs (diameter $1 \mathrm{~cm}$ ) were exposed to a flow-through of unfiltered natural fjord water heated or cooled to different temperatures $\left(5,10,15,20\right.$ and $25^{\circ} \mathrm{C}, 3$ replicates) in low light levels $\left(20 \mu \mathrm{mol} \mathrm{m} \mathrm{m}^{-2} \mathrm{~s}^{-1}\right)$. After $3 \mathrm{wk}$, the light transmission through the biofilm was measured at different wavelengths between 280 and $610 \mathrm{~nm}$ (Hidex Chameleon).

Variability of microbial fouling pressure with depth. Plexiglas discs were exposed to natural fouling at different depths $(0,1,2,3,4,5$ and $6 \mathrm{~m} ; 3$ replicates $)$ in Kiel Fjord in June 2008. The water temperature during this incubation was between 16 and $18^{\circ} \mathrm{C}$ at all depths. After $2 \mathrm{wk}$, light absorbance by the developed biofilm was measured as described above.

Quantitative and qualitative analyses of biofilms. Harvesting the biofilm on algae was done by swabbing a defined area of the fouled surface (either 1 or $2 \mathrm{~cm}^{2}$ ) with a sterile cotton tip, followed by intense vortexing of the tip in an Eppendorf vial containing $1 \mathrm{ml}$ of sterile seawater. In grazing experiments, bacteria were swabbed from grazed thallus portions. Bacteria and diatoms were subsequently quantified by several methods. The relative abundance of the photoautotrophs (mainly diatoms, sometimes also cyanobacteria) in a $100 \mu$ l subsample of the biofilm suspension was assessed as fluorescence of chlorophyll a (excitation $485 \mathrm{~nm}$, emission $677 \mathrm{~nm}$ ) using a platereader (Hidex Chameleon). Subsequently, the suspension was filtered through a $5 \mu \mathrm{m}$ pore filter to eliminate the photoautotrophs. DNA of particles $<5 \mu \mathrm{m}$ (mostly bacteria) was stained with Syto 9 (500 nM, 10 min staining time). The relative bacterial density in a $100 \mu \mathrm{l}$ subsample was then assessed as fluorescence (excitation 477 to $491 \mathrm{~nm}$, emission $540 \mathrm{~nm}$ ) using the same equipment. For a more absolute measure of bacterial abundance, bacterial suspensions were filtered through a blackened nitrate cellulose filter $(0.2 \mu \mathrm{m}$ pore width, DHI), DAPI-stained and counted under an epifluorescence microscope (Coleman 1980). The bacterial composition of biofilms was investigated by DGGE as described in Lachnit et al. (2009) and/or by restriction fragment length polymorphism (RFLP) followed by sequencing. For this last approach, total DNA was extracted and then amplified with a eubacterial pair of primers: $355 \mathrm{~F}$ forward $\left(5^{\prime}\right.$-ACT CCT ACG GGA GGC
AGC-3'; Amann et al. 1990) and 1492R reversal (5'-GGY TAC CCT GTT ACG ACT T-3'; Eden et al. 1991). RFLP analysis was performed using HaeIII (Boehringer Mannheim Biochemicals) as a restriction enzyme. The band patterns obtained were analyzed using the GelBuddy software (www.gelbuddy.org) and compared using the Primer software package. To this end, migration distance was assimilated to species and the sum of presences/absences of bands at given distances constituted the community composition, which was compared among samples by a Bray-Curtis similarity analysis (for more details on the RFLP and its analysis, see Dobretsov et al. 2006a). In order to identify the bacterial species that were represented by different bands, the pre-cut DNA was cloned using the pCR4-Topo TA cloning kit (Invitrogen) according to the user's manual. In total, 144 positive clones were further sequenced and their sequences were aligned with the Basic Local Alignment Search Tool nucleotide database of the National Center for Biotechnology Information for rough identification.

Biofilms on Fucus vesiculosus. To assess variability in bacterial epibiosis between conspecific algae, we collected 15 individuals of $F$. vesiculosus growing between 1 and $10 \mathrm{~m}$ apart in the same habitat. The biofilm swabbed from $F$. vesiculosus was quantified by fluorescence and qualified by RFLP and cloning. To assess whether putative stress affects microbial fouling on F. vesiculosus, we examined the density, and occasionally also the composition, of biofilms on algal individuals with different stress histories: in the natural shallow habitat (presumably unstressed), or maintained in flow-through aquaria (unfiltered fjord water, 1-2 $1 \mathrm{~min}^{-1}$ ) for $2 \mathrm{wk}$ under a variation of stress conditions applied either singly or in combination, i.e. (1) 'unstressed' (natural sunlight, ambient fjord water temperature $\left(16^{\circ} \mathrm{C}, \mathrm{SD} 1.5^{\circ} \mathrm{C}\right),(2)$ 'shaded' $(20 \%$ of natural sunlight, fjord temperature), (3) pulse-warmed to $35^{\circ} \mathrm{C}$ for $2 \mathrm{~h}$ (simulating periodic heating during emersion) which resulted in an increase of mean temperature to $17.4^{\circ} \mathrm{C}$ and an increase of the temporal variability of temperature (SD $\left.3.8^{\circ} \mathrm{C}\right),(4)$ artificial irradiation (Osram Fluora L 36W/77 and Osram Lumilux L $36 \mathrm{~W} / 840$ ) of $20,30,50$, or $75 \mu \mathrm{mol} \mathrm{m} \mathrm{m}^{-2} \mathrm{~s}^{-1}$ during daylight hours (where levels below 30 are considered stressfully low), and (5) grazing by ca. 1 isopod Idotea baltica (a major local consumer of $F$. vesiculosus) per $10 \mathrm{~g}$ wet weight of alga, which is a consumer-prey ratio commonly found in the field (bacteria swabbed from grazed algae, Weinberger et al. 2008). The treatment duration of typically 2 (rarely 3 ) wk was chosen because, with regard to other response variables (e.g. antifeeding resistance), F. vesiculosus was shown to react to stress with a lag of 10 to $14 \mathrm{~d}$ (Rohde \& Wahl 2008a). Irradiation was monitored by a LI-1400 quantameter (LI-COR), and temperature treatments were 
monitored using loggers $\left(\mathrm{HOBO}{ }^{\circledR}\right.$, Onset Computer Corporation). In the experiment investigating the interactive effects of light and grazing on the composition of epibacterial communities (144 clones of epibacteria were sequenced), the high work load necessary for the cloning and sequencing of entire communities required low replication $(n=2)$. Consequently, in this case no statistical analysis was run and results should be considered descriptive.

Analysis of fouling-modulating ability. The chemical fouling-modulating activity was usually tested in surface extracts containing only metabolites found on the thallus surface and the adhering boundary layer, and only occasionally in whole extracts of an alga, which were obtained by extracting the entire tissue of an alga and not only its surface boundary layer. After spin-drying the algae in a salad spinner for 20 s, Fucus vesiculosus plants were surface-extracted by dipping them in a hexane:methanol (1:1) mixture for $10 \mathrm{~s}$ (for detailed methods see Lachnit et al. 2010). For the complete extraction, algae were freeze-dried, ground and extracted with dichloromethane:methanol (1:1). In all cases, the extracts were dried, weighed, re-dissolved in dimethylsulphoxide (DMSO) and tested at natural concentrations expressed as mg metabolites per $\mathrm{ml}$ F. vesiculosus extracted. For the surface extraction, the extracted volume was calculated as algal surface area $\times 30 \mu \mathrm{m}$ estimated boundary layer thickness. Surface area was obtained by image analysis (ImageJ, National Institutes of Health) of photos. Since the water in the surface extraction represents the volume of the boundary layer after spin-drying the alga, the boundary layer thickness could be calculated as the volume of the water residue after evaporation of the organic solvents divided by surface area (details in Lachnit et al. 2010). Bacteria and diatoms were never exposed to DMSO concentrations exceeding $4 \%$, since DMSO becomes toxic beyond 5\% (pilot tests).

Target organisms in the antimicrobial bioassays were common marine bacteria (Bacillus aquimaris and Cytophaga sp.), strains isolated from local algal thalli (Pseudoalteromonas sp., FUCUS2 [unidentified], Tenacibaculum adriaticum, Flavobacterium sp., Rheinheimeria baltica and Pseudoalteromonas tunicata) and a marine diatom (Amphora sp.). Two responses were quantified, i.e. settlement and growth (population growth by cell division). For the settlement assay, pregrown bacteria were transferred to a Greiner multiwell plate (96 wells, flat bottom). Crude extracts were dissolved in DMSO (4\% final concentration) and added at natural concentrations to half of the replicates, while in the other half of the wells microbes were allowed to settle in the absence of extract (but with DMSO). The multi-well plates were placed on a shaking table at $28^{\circ} \mathrm{C}$ (the temperature of optimal growth), and bacteria were allowed to attach for $1 \mathrm{~h}$. Subsequently, the bacterial suspension was removed from the wells, and non-attached cells were removed by gently rinsing twice with sterile filtered seawater. Bacteria were quantified by fluorescence after DNA staining (see above). For the growth assay, bacteria that had settled in the absence of extracts for $1 \mathrm{~h}$ were allowed to grow for $24 \mathrm{~h}$ in medium with and without extract on a shaker at $28^{\circ} \mathrm{C}$. This relatively high temperature was chosen because the strains grew best in warmer conditions: extracts being concentrated at $30^{\circ} \mathrm{C}$ should not be degraded at $28^{\circ} \mathrm{C}$, and comparative pilot tests had shown that the strains' average sensitivity to algal extracts did not differ between 20 and $28^{\circ} \mathrm{C}$ experimental temperature $(t$-test, $\mathrm{n}=35, \mathrm{p}=0.09)$. After the growth phase, the suspension was removed from the wells, and fluorescence of attached bacteria was measured as described above. The strength of algal resistance to bacterial fouling is expressed as the $\log$ effect ratio (i.e. decimal logarithm of the ratio of target strain abundance in the presence versus absence of extract; Wahl et al. 2004). Assays with diatoms differed from those with bacteria only insofar as settlement time was $3 \mathrm{~h}$ rather than $1 \mathrm{~h}$ (for growth, $120 \mathrm{~h}$ rather than $24 \mathrm{~h}$ was allowed), the experimental temperature was $20^{\circ} \mathrm{C}$ and chlorophyll a fluorescence rather than Syto 9 fluorescence was measured. In one experiment, the paper disc diffusion assay was used: $20 \mu \mathrm{l}$ of the extract solution were transferred to a $6 \mathrm{~mm}$ paper disc and evaporated. These discs were deposited on agar inoculated with one of the bacterial target strains. The concentration of the solution was such that it would produce a near-natural concentration after diffusing into an agar hemisphere of twice the diameter of the disc (i.e. $12 \mathrm{~mm}$ ) - a typical diffusion rate within $24 \mathrm{~h}$ as determined beforehand by a variety of dyes. Antimicrobial activity was quantified as the size (area or diameter) of the inhibition zone with regard to a given target strain. Since strains differed in sensitivity, when the average activity (versus several strains) of different extracts was to be compared, effects of the extracts were ranked within each target strain and an average rank was then calculated per extract.

Variability of antimicrofouling resistance. Fucus vesiculosus individuals, microbial strains and response variables: Antimicrobial resistance was compared using extracts from $70 \mathrm{~F}$. vesiculosus individuals collected at different sites in Kiel Fjord in 2008 and 2009. The variability of effect strength was assessed for the 8 target strains used (see above) and for the 2 response variables examined (settlement and growth) using the bioassays described.

Sites and seasons: Individual Fucus vesiculosus plants were collected from 3 sites in the Kiel Bight (Strande, $54^{\circ} 25^{\prime} 23.51^{\prime \prime} \mathrm{N}, 10^{\circ} 10^{\prime} 34.85^{\prime \prime} \mathrm{E}$; Huberts- 
berg, $54^{\circ} 22^{\prime} 47.00^{\prime \prime} \mathrm{N}, 10^{\circ} 32^{\prime} 23.33^{\prime \prime} \mathrm{E}_{\text {; }}$ and Aschau, $\left.54^{\circ} 27^{\prime} 45.51^{\prime \prime} \mathrm{N}, 9^{\circ} 56^{\prime} 04.98^{\prime \prime} \mathrm{E}\right)$ at monthly intervals over 1 yr. Whole extracts were tested for activity against settlement and growth (platereader assays) of a variety of bacterial strains. The level of replication per site and month was 3 , but since no differences were found between sites, all individuals of a given month were treated as 1 sample with 9 replicates.

Depth (light): Individual Fucus vesiculosus plants were exposed at different depths below MSSL $(1,4$ and $6 \mathrm{~m}$ ), attached to ropes for $2 \mathrm{wk}$. Replication was 3fold. Subsequently, algae were surface-extracted. Anti-growth activity of each algal individual was quantified using the paper disc diffusion assay. The level of sub-replication per algal individual in the bioassay was 3 .

Low light: Fucus vesiculosus was maintained for $10 \mathrm{~d}$ in flow-through outdoor aquaria ( $30 \mathrm{l}$, ca. $50 \mathrm{l} \mathrm{h}^{-1}$ ). Half of the aquaria were exposed to natural sunlight, while the remaining aquaria were covered with 3 layers of black mosquito gauze which reduced incoming sunlight by $80 \%$. Replication was 6 -fold. After the treatment, antisettlement activity against Bacillus aquimaris of the total methanol:hexane (1:1) extract was assessed. In a further experiment, algae (in this case Fucus vesiculosus from the Canadian east coast) were exposed at 6 levels of shading from natural sunlight $(0,43,68,81,90$ and $95 \%$ shading). After $1 \mathrm{wk}$, the activity of methanol surface extracts against the growth of bacteria was tested. Replication was 3-fold.

Temperature $\times$ grazing: Fucus vesiculosus plants were maintained individually for $2 \mathrm{wk}$ at different temperatures $\left(8,12,16,21\right.$ and $\left.23^{\circ} \mathrm{C}\right)$. Nested within each temperature treatment, 6 aquaria contained Idotea baltica grazing on $F$. vesiculosus, while the algae in the other 6 aquaria were ungrazed. Irradiation was $70 \mu \mathrm{mol} \mathrm{m} \mathrm{m}^{-2} \mathrm{~s}^{-1}$ in a $16 \mathrm{~h}$ light:8 h dark cycle. After $2 \mathrm{wk}$, the $F$. vesiculosus individuals were surfaceextracted, and their activity with regard to settlement and growth of Amphora sp. and Bacillus aquimaris was assessed using the platereader assay.

Statistics. When data were normally distributed and showed homogeneous variances, we used $t$-tests or ANOVAs (1- or 2-factorial) for the comparison of treatment effects, and linear or non-linear regression for the exploration of relationships. For procedures where normality and homoscedasticity were prerequisites but where replication was too low to test the distribution parameters, we either used non-parametric procedures or followed recommendations to use parametric testing but reduced the level of significance to 0.01 in order to avoid Type 1 errors (Underwood 1997, Wakefield \& Murray 1998).

\section{RESULTS}

\section{Underwater light and temperature regime}

On a yearly average, light diminishes exponentially with depth in Kiel Fjord. Already at a depth of $0.5 \mathrm{~m}$, less than $50 \%$ of the incoming light is available for photosynthesis, $30 \%$ is available at $1 \mathrm{~m}, 10 \%$ at $3 \mathrm{~m}$ and $5 \%$ at $5 \mathrm{~m}$. The absolute amounts obviously depend on the seasonal level of irradiance which varied between a noon maximum of $1780 \mu \mathrm{mol} \mathrm{m}^{-2} \mathrm{~s}^{-1}$ in July and a noon minimum of $5 \mu \mathrm{mol} \mathrm{m}^{-2} \mathrm{~s}^{-1}$ in December. Besides the mean of irradiation, the amplitude of fluctuation also diminished drastically between MSSL and $3 \mathrm{~m}$ depth (Fig. 1). In the first meter of water, where Fucus vesiculosus is

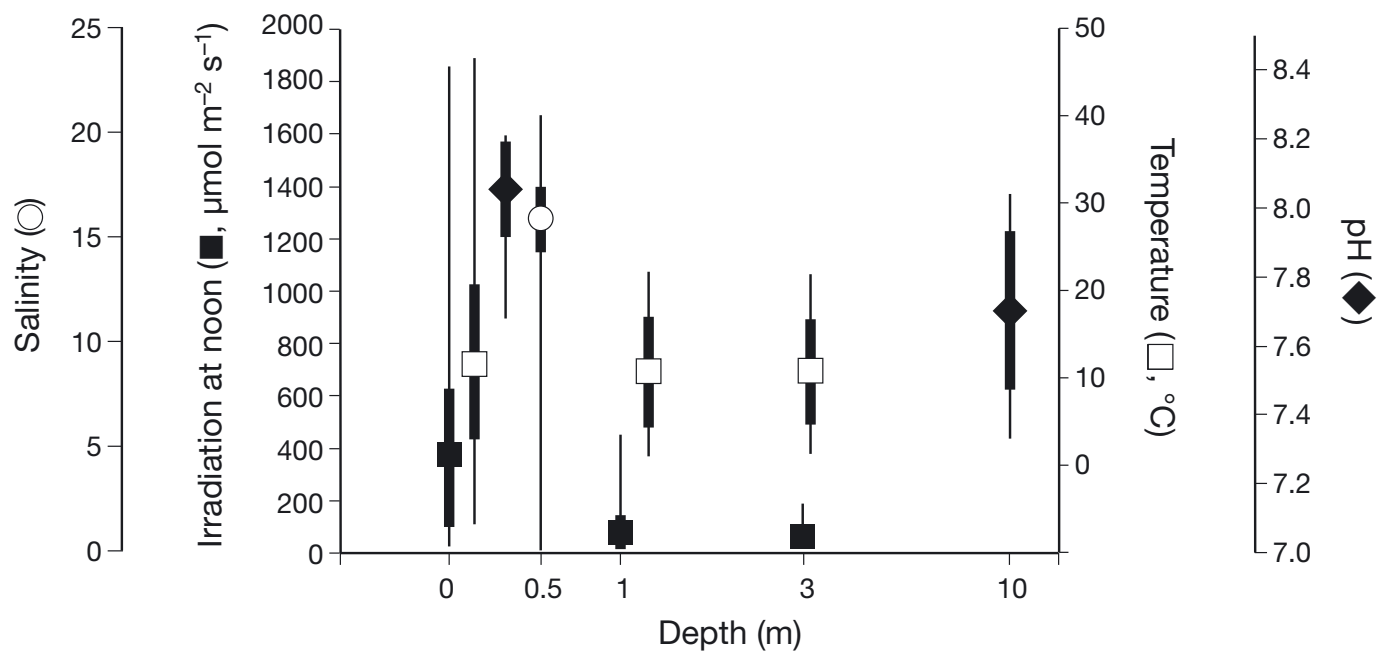

Fig. 1. Underwater stress regime. Mean (central symbol), SD (thick lines) and extremes (min.-max.: thin lines) of irradiation ( $\mathbf{\square})$, temperature $(\square), \mathrm{pH}(\diamond)$ and salinity $(\mathrm{O})$ at various depths based on numerous measurements in Kiel Fjord between May 2008 and March 2009 (irradiation at noon, temperature) and between May and October 2009 (pH, salinity) 
most abundant, irradiation ranges (SD) between 0 and $700 \mu \mathrm{mol} \mathrm{m} \mathrm{m}^{-2} \mathrm{~s}^{-1}$ with occasional extreme peaks of almost $2000 \mu \mathrm{mol} \mathrm{m} \mathrm{m}^{-2} \mathrm{~s}^{-1}$. F. vesiculosus - in the season and habitat sampled - cannot exploit irradiation levels below, on average, $20 \mu \mathrm{mol} \mathrm{m}{ }^{-2} \mathrm{~s}^{-1}$ (compensation point range is 35 in summer and 12 in winter; Middelboe et al. 2006, Nygard \& Dring 2008), and fluctuations beyond this limit will render light temporarily unsuitable for photosynthesis. On a year-round average, the portion of the day during which light is available at exploitable intensity decreases with depth: $38 \%$ (9.12 h) on land; $20 \%$ (4.8 h) at $1 \mathrm{~m}, 12 \%(2.9 \mathrm{~h})$ at $3 \mathrm{~m}$ and $4 \%$ $(0.96 \mathrm{~h})$ at $5 \mathrm{~m}$. In contrast to light, mean temperature did not differ in the depth range considered. Temperature fluctuations, however, decreased conspicuously from MSSL to $3 \mathrm{~m}$ depth. Stressful temperatures $\left(>20^{\circ} \mathrm{C}\right.$ i Rohde et al. 2004) are most common in the first meter. Salinity ranged from 16 to 23 (mean = $18.2 \pm 1.8), \mathrm{pH}$ from 7.5 to 8.1 (mean $=$ $7.83 \pm 0.20)$ and $\mathrm{pCO}_{2}$ from 52 to $234 \mathrm{~Pa}$ $($ mean $=112.9 \pm 60.6 \mathrm{~Pa})$; values are $\pm \mathrm{SD}$.
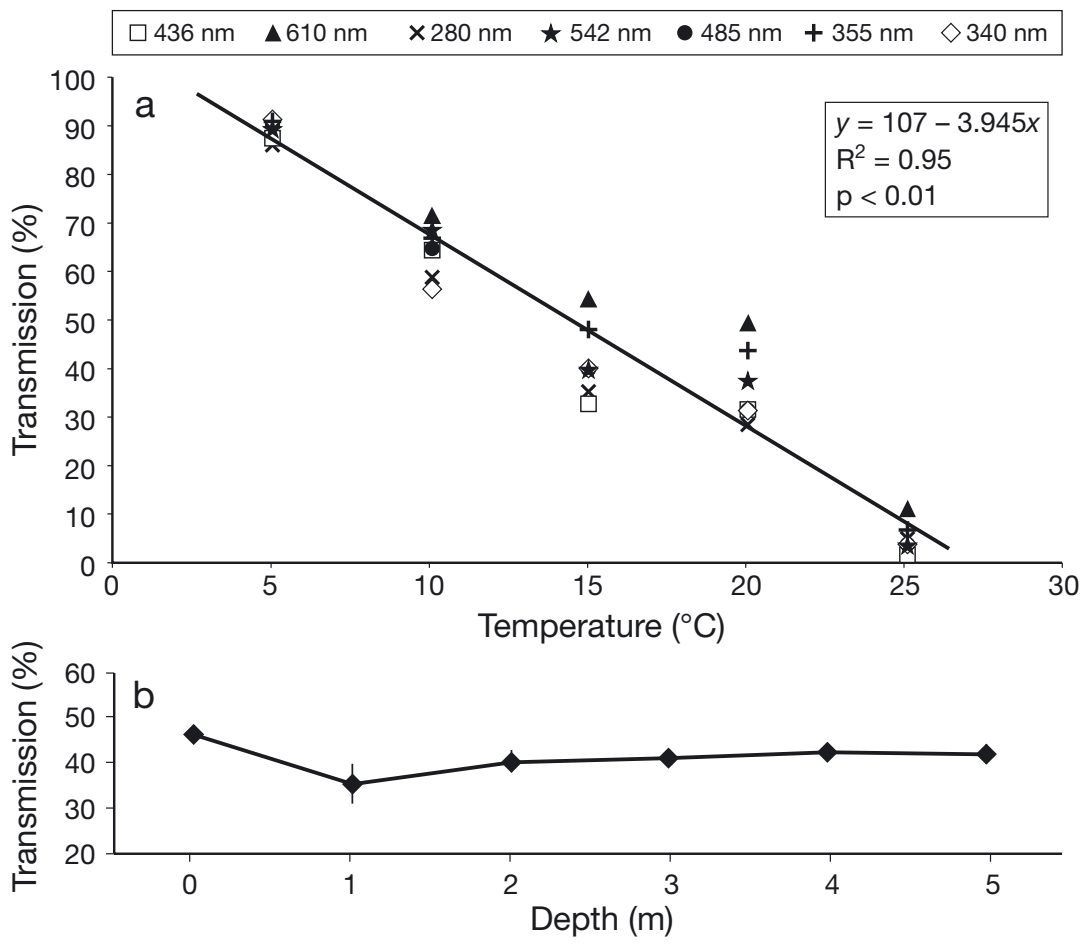

Fig. 2. Fouling pressure as assessed by reduction in light transmission through a 2 to 3 wk old biofilm grown under (a) variable temperature regimes in flow-through with untreated fjord water ( 3 wk exposure, transmission at 340 to $610 \mathrm{~nm}, \mathrm{n}=3$ ) and (b) at different water depths in situ ( $2 \mathrm{wk}$ exposure, $485 \mathrm{~nm}, \mathrm{n}=3$ ). Error bars are $95 \%$ CI

\section{Variability of biofilms and potential causes}

Temperature

Shading by biofilms, a rough measure of thickness and a direct measure of their impact on algal photosynthesis, increased with temperature (Fig. 2a). Per degree of warming, the shading effect of a 3 wk old biofilm increased by $4 \%$ on average, exceeding $90 \%$ at $25^{\circ} \mathrm{C}\left(\mathrm{R}^{2}=0.95, \mathrm{p}<0.01\right)$. The density of diatoms doubled every $6^{\circ} \mathrm{C}$ of warming and the density of bacteria doubled every $7^{\circ} \mathrm{C}$ of warming (as quantified by fluorescence, data not shown). As this is a single measurement, it reflects the rate of colonization (i.e. fouling pressure per $3 \mathrm{wk}$ ) at different temperatures. Interestingly, the absorption by natural biofilms does not seem to be wavelength-dependent across most of the UVA and photosynthetically active radiation range.

\section{Depth (light)}

The accumulation rates of biofilms on the transparent Plexiglas discs hardly varied with depth of expo- sure (Fig. 2b). At all water depths, the decrease in light transmission caused by the biofilms ranged between 35 and $48 \%$. Thus, at the same temperature, the microbial fouling pressure (in terms of shading effect) seems to be quantitatively relatively constant in the depth range of Fucus vesiculosus distribution.

\section{Host individual}

The similarity of epibacterial communities based on the analysis of 144 clones from 15 Fucus vesiculosus individuals sampled on the same day from the same site ranged between 70 and $90 \%$. Epibacterial density on average $( \pm \mathrm{SD})$ was $7.7 \times 10^{6} \pm 2.2 \times 10^{6}$ cells per $\mathrm{cm}^{2}$ of algal thallus, which corresponds to a cover by the biofilm of $3.8 \pm 1.1 \%$, assuming an average projected area of $0.5 \mu \mathrm{m}$ per bacterial cell. The variability in biofilm cover among individual algae corresponded to a coefficient of variation (CV) of ca. $30 \%$. Diatom cover varied by a factor of 9 and the CV was around $75 \%$ for all thallus parts examined. Cover by epibiotic bacteria or diatoms did not differ between young and old thallus parts (paired $t$-test, $\mathrm{p}>0.05$ for both colonizer groups). 
Light reduction and warming led to an increase of epibacterial density. After 2 wk in a flow-through aquarium with natural sunlight and ambient fjord temperature, epibacterial coverage was $29 \pm 13 \%$ (mean $\pm \mathrm{SD}$ ) for algae, $56 \pm 20 \%$ for shaded algae and $95 \pm$ $36 \%$ for pulse-warmed algae (Table 1). This increase in the density of epibacteria was not accompanied by a notable increase of variability among individuals (CV).

\section{Light $\times$ temperature}

The effects of light reduction and warming on the Fucus vesiculosus biofilm are interactive and partly counterintuitive (Table 2).Warming from 15 to $20^{\circ} \mathrm{C}$ increased epibacterial numbers under high light of $70 \mu \mathrm{mol} \mathrm{m} \mathrm{m}^{-2} \mathrm{~s}^{-1}$ (e.g. $24 \mathrm{~h}$ dose at $1 \mathrm{~m}$ depth in September) by $30 \%$, but decreased their numbers under weak light of $30 \mu \mathrm{mol} \mathrm{m}{ }^{-2} \mathrm{~s}^{-1}$ (e.g. 24 dose at $3 \mathrm{~m}$ depth in September) by $56 \%$ on average. At lower tempera-

Table 1. Epibacterial density expressed as \% cover on Fucus vesiculosus in the field, and after $2 \mathrm{wk}$ in flow-through outdoor aquaria with different treatments (unstressed: natural sunlight, fjord temperature; shaded: $20 \%$ sunlight; warmed: slightly increased mean and variance of temperature; $\mathrm{n}=3$ ). Variability of epibacterial density among replicate individuals, expressed as coefficient of variation, is not significantly affected by stress (1-way ANOVA and Tukey's HSD post hoc)

\begin{tabular}{|lccccc|}
\hline ANOVA & $\mathrm{SS}$ & $\mathrm{df}$ & $\mathrm{MS}$ & $F$ & $\mathrm{p}$ \\
\hline $\begin{array}{l}\text { Treatment } \\
\text { Error }\end{array}$ & $\begin{array}{r}30254.50 \\
9091.88\end{array}$ & 28 & 10084.83 & 31.05 & $<0.001$ \\
Tukey's HSD & & Field & Unstressed & Shaded & Warmed \\
\hline 1 & & & 0.045 & 0.0002 & $<0.001$ \\
2 & Field & & 0.012 & $<0.001$ \\
3 & Unstressed & 0.045 & 0.012 & & $<0.01$ \\
4 & Shaded & 0.0002 & 0.007 & \\
\hline
\end{tabular}

Table 2. Effects of light ( 75 versus $30 \mu \mathrm{mol} \mathrm{m} \mathrm{m}^{-2} \mathrm{~s}^{-1}$ ) and temperature (15 versus $20^{\circ} \mathrm{C}$ ) on the density of bacteria on Fucus vesiculosus (2-way ANOVA and Tukey's HSD post hoc)

\begin{tabular}{|lrrrrrc|}
\hline ANOVA & SS & df & MS & \multicolumn{1}{c}{$F$} & p \\
\hline Temperature & 64.849 & 1 & 64.849 & 4.22 & 0.047 \\
Light & 183.980 & 1 & 183.980 & 11.97 & 0.0014 \\
Temperature $\times$ Light & 662.783 & 1 & 662.783 & 43.12 & $<0.001$ \\
Error & 553.285 & 36 & 15.369 & & \\
& & & & & & \\
Tukey's HSD & Temperature & Light & 1 & 2 & 3 & 4 \\
\hline 1 & 15 & 30 & & 0.14 & 0.0002 & 0.75 \\
2 & 15 & 75 & 0.14 & & 0.002 & 0.015 \\
3 & 20 & 30 & 0.0002 & 0.002 & & $<0.001$ \\
4 & 20 & 75 & 0.75 & 0.015 & 0.0002 & \\
\hline
\end{tabular}

Light $\times$ grazing

The composition of the epibacterial community was affected by grazing and irradiation (Fig. 3, Table 3). In the absence of grazers, shading reduced the proportion of cyanobacterial strains in the biofilm while enhancing the relative abundance of Gammaproteoteria. In the absence of shading stress, grazing Alphaproteobacteria and disfavoured CyanoAlphaproteobacteria and completely eliminated Cyanoat this taxonomic level seems to be decreased by the concerted action of the 2 stressors since the number of groups present was reduced from 6 to 4 , and the dominance of Bacteroidetes increased from $<25 \%$ in the 3 other scenarios to $>50 \%$ under double stress. Grazing did not affect the number of epibacteria on Fucus vesiculosus ( $t$-test, $t=0.24, \mathrm{n}=100, \mathrm{p}=0.8)$.

\section{Variability in algal modulation of epibiotic biofilms}

Variability among Fucus vesiculosus individuals and among target strains

All Fucus vesiculosus individuals (n = 30) tested for anti-settlement and antigrowth activity against Cytophaga sp. and Bacillus aquimaris in this survey were active (see the min.-max. spread in Fig. 4a). The modulating effects varied substantially between the 2 target strains and the 2 response variables (growth versus settlement) measured. Anti-growth activity was generally stronger than anti-settlement activity, particularly versus Bacillus (results of $t$ tests in Fig. 4a). Among all tested F. vesiculosus individuals, anti-settlement and anti-growth strengths did not correlate for either of the 2 target bacteria (Cytophaga: $\mathrm{R}^{2}=-0.04, \mathrm{p}=0.59$, Bacillus: $\left.\mathrm{R}^{2}=0.14, \mathrm{p}=0.06\right)$. The resistance strength with regard to settlement did relate weakly between target species $\left(\mathrm{R}^{2}=\right.$ 


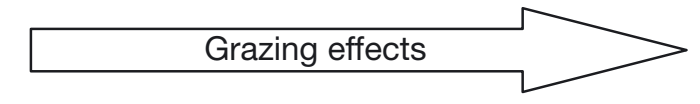

Low light

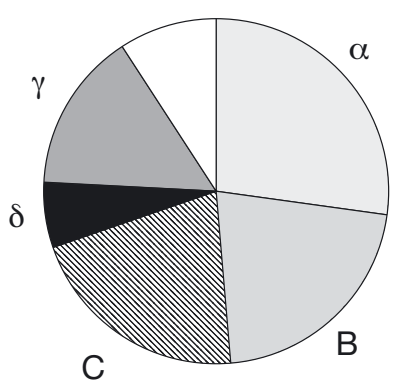

High light

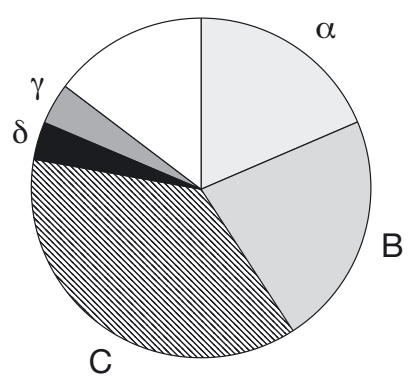

B

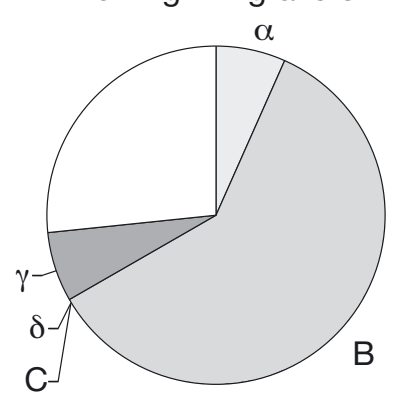

High light + grazers

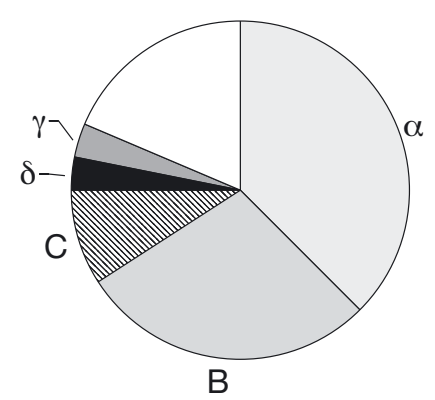

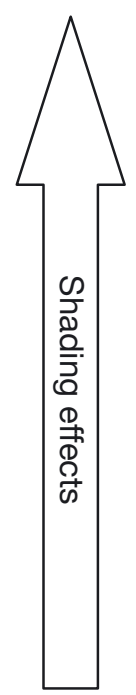

strongly repelled than Bacteroidetes, which, in the case of Flavobacterium, were even attracted by the $F$. vesiculosus extracts.

\section{Variability among seasons}

Independently of site, the anti-settlement activity of Fucus vesiculosus showed a clear seasonal pattern. The change of activity strength during the course of a year describes a sinus curve $(y=-0.21+0.25 \times \cos [0.497 x+1.97]$, $\mathrm{R}^{2}=0.74$; Fig. 5a). Strongest repellence was found in spring and early summer (March, April and June), and the weakest in late summer and autumn (July, August, September, October and December). Growth and reproductive cycles (Fig. 5b) were assessed in separate projects (data courtesy of $\mathrm{M}$. Hamann and K. Maczassek, IFM-GEOMAR). Growth was low in spring, reached a maximum rate $(6 \%$ surface area increase per day) in June and ceased in October. Reproduction was maximal in spring (March to May), with a second small peak in autumn and ran at a reduced level throughout the entire year.

Fig. 3. Interactive influence of grazing and light on the composition of an epibiotic bacterial biofilm on Fucus vesiculosus: relative shifts in the prevalence of different groups of bacteria found on $F$. vesiculosus exposed to 2 levels of irradiation (low light: $20 \mu \mathrm{mol} \mathrm{m} \mathrm{m}^{-2} \mathrm{~s}^{-1}$; high light: $59 \mu \mathrm{mol} \mathrm{m}{ }^{-2} \mathrm{~s}^{-1}$ ) and 2 levels of grazing (with and without isopods) for 2 wk. $\alpha$ : Alphaproteobacteria; B: Bacteroidetes; C: Cyanobacteria; $\gamma$ : Gammaproteobacteria; $\delta$ : Deltaproteobacteria; white section: remaining groups $(n=5)$

\section{Variability of defense with depth}

Table 3. Interactive effects of grazing and shading on the biofilm composition on Fucus vesiculosus. Shown are moderate $(-,+)$ and large $(--,++)$ decreases and increases, respectively, in the proportional abundance of major groups as quantified in Fig. 3. Empty cells indicate weak effect. Light-: $20 \mu \mathrm{mol} \mathrm{m} \mathrm{m}^{-2} \mathrm{~s}^{-1}$; Light+: $50 \mu \mathrm{mol} \mathrm{m}{ }^{-2} \mathrm{~s}^{-1}$; $\mathrm{G}$-: without grazers; $\mathrm{G}+$ : with grazers

\begin{tabular}{|lcccc|}
\hline \multirow{2}{*}{ Group } & \multicolumn{2}{c}{ Grazing } & \multicolumn{2}{c|}{ Shading } \\
& Light- & Light+ & G- & G+ \\
\hline Alphaproteobacteria & -- & + & & -- \\
Bacteroidetes & ++ & & & ++ \\
Cyanobacteria & -- & -- & -- & -- \\
Gammaproteobacteria & - & & ++ & \\
Deltaproteobacteria & - & & & - \\
\hline
\end{tabular}

$0.29, \mathrm{p}=0.01$ ), while this was not the case for growth $\left(R^{2}=0.09, p=0.1\right)$. When testing the sensitivity of further sediment or epibiotic bacterial strains to the extracts of another batch of $30 \mathrm{~F}$. vesiculosus individuals, we observed strong strain-specificity in the responses (Fig. 4b). As a trend, Gammaproteobacteria were more
When exposed at different depths for $2 \mathrm{wk}$, antibacterial resistance was significantly affected (Table 4). The resistance of algae grown at $6 \mathrm{~m}$ depth was reduced by almost $50 \%$ compared to algae grown at the intermediate depth $(4 \mathrm{~m})$ and was, albeit non-significantly, less than that of algae grown at $1 \mathrm{~m}$ depth.

\section{Variability of defense with light regime}

While the algae exposed to full sunlight exhibited moderate anti-settlement activity (34\% reduction of settlement by Bacillus aquimaris), this resistance was significantly (1-tailed $t$-test, $\mathrm{n}=6, \mathrm{p}=0.03$ ) reduced by $22 \%$ when the algae were shaded to a level which corresponds to a water depth of $1.5 \mathrm{~m}$ for $10 \mathrm{~d}$. Antibiotic resistance of algae exposed to a wider and more finely resolved shading gradient showed a more complex pattern. The relatively weak antibiotic resistance of the more apolar extract was not affected by light. In 

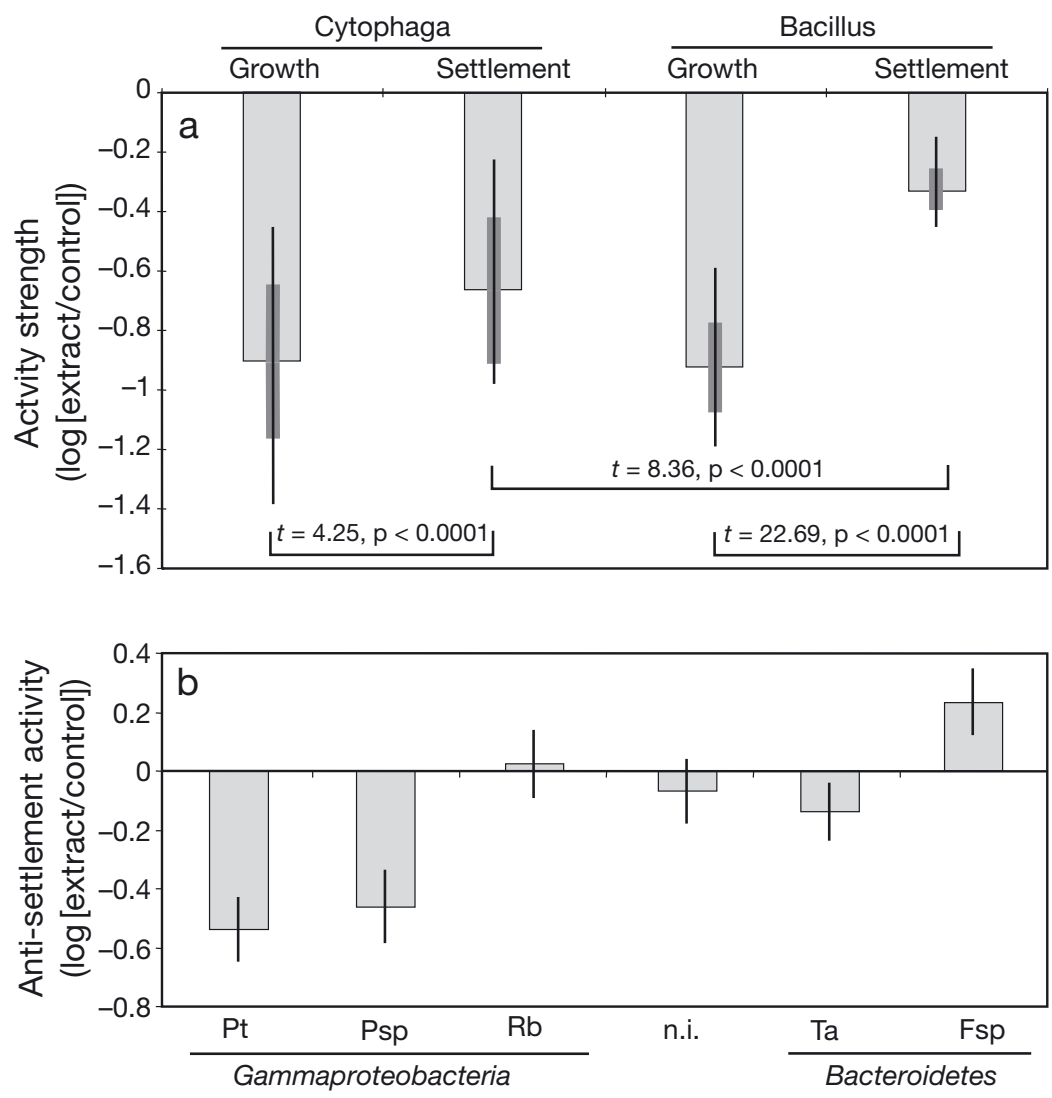

Fig. 4. Contingency of resistance strength. (a) Chemical resistance of Fucus vesiculosus to bacteria varies between target organisms (Bacillus aquimaris versus $C y$ tophaga sp.) and between response variables (settlement versus growth). Error bars indicate the variability of antimicrobial activities among $F$. vesiculosus genotypes tested, thick lines are SD and thin lines are min.-max. (pairwise $t$-tests, $\mathrm{n}=$ 25). (b) Effect of $F$. vesiculosus metabolites on bacterial settlement varies among culturable strains isolated from its own thallus from strongly repellent (negative values) to moderately attractive (positive values). Error bars are 95\% CI. Pt: Pseudoalteromonas tunica; Psp: Pseudoalteromonas sp.; Rb: Rheinheimeria baltica; Ta: Tenacibaculum adriaticum; Fsp: Flavobacterium sp.; n.i.: non-identified marine

contrast, the stronger activities of the more polar extract were significantly stronger under weak light $\left(12 \mu \mathrm{mol} \mathrm{m}{ }^{-2} \mathrm{~s}^{-1}\right)$ than under very weak $\left(<10 \mu \mathrm{mol} \mathrm{m}{ }^{-2}\right.$ $\left.\mathrm{s}^{-1}\right)$ or intermediate light $\left(36 \mu \mathrm{mol} \mathrm{m} \mathrm{m}^{-2} \mathrm{~s}^{-1}\right.$; Fig. 6).

\section{Temperature and grazing}

With few exceptions, neither temperature nor grazing had any conspicuous influence on antifouling resistance (Fig. 7). Only $5.5 \%$ of the 180 post hoc pairwise comparisons were significant, which in itself can be considered a random outcome. Settlement and growth of the bacterial and settlement of the diatom target strains were significantly inhibited at all temperatures (with the single exception of ungrazed algae at $8^{\circ} \mathrm{C}$ versus Bacillus) and both in the absence and presence of consumers. In contrast, growth of diatoms was not, or only weakly, inhibited. Within a given temperature regime, grazing (which induced a chemical antigrazing resistance in the algae in the same experiment; see F. Weinbergerpers. obs.) never affected the antimicrobial resistance, with the unique exception of diatom growth at $12^{\circ} \mathrm{C}$. No indication for an interaction between the induction of antigrazing resistance and the deployment of antifouling resistance was detected. No indication of a general decrease or increase of resistance strength with higher temperatures was evident. In the cases where resistance was affected by temperature, the effect size was relatively small (Fig. 7, Table S1 in the supplement at www.int-res.com/articles/suppl/m411 p033_supp.pdf).

\section{DISCUSSION}

Epibionts may act as an ecological lever and modulate the interactions of the host with its abiotic and biotic environment (Dobretsov 2008, Harder 2008, Jormalainen et al. 2008, Wahl 2008). The studies cited in these reviews show that epibionts enhance or buffer the impact of abiotic stressors (e.g. UV radiation, desiccation and drag) as well as biotic interactors (e.g. pathogens, parasites, consumers, mates, competitors and foulers) on their host. In the present study we demonstrated that within 2 to $3 \mathrm{wk}$, unhindered microfouling reduces the amount of photosynthetic active radiation at an alga's thallus surface by about $50 \%$ at $15^{\circ} \mathrm{C}$ and $>90 \%$ at $25^{\circ} \mathrm{C}$ (Fig. 2a). Such potential impacts of macro- and microfoulers should favour the evolution in the host of some capacity to modulate the quantity and composition of, for instance, biofilms. The resulting biofilm may be harmless or even beneficial to the host (Armstrong et al. 2001, Lee et al. 2006).

In this investigation we studied the quantity and composition of biofilms on Fucus vesiculosus, how the biofilm changes with stress, how the abiotic stress potential of a typical $F$. vesiculosus habitat looks, how selected environmental factors affect microfouling pressure and whether the macroalga's capacity of chemical modulation of microfouling is impacted by stress. 

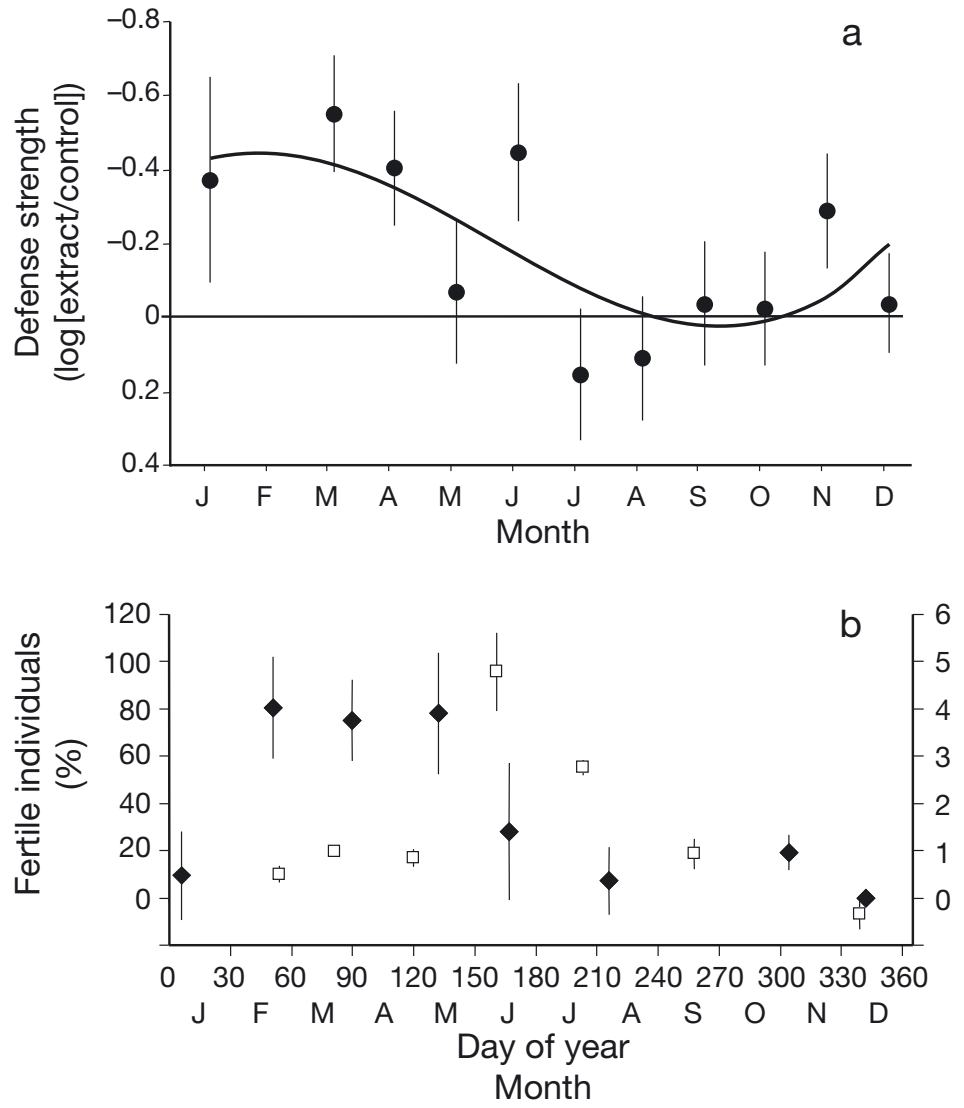

Fig. 5. Seasonal cycles in Fucus vesiculosus as assessed in monthly to bimonthly intervals in 2008 and 2009. (a) Seasonal variability of mean antibacterial resistance of $F$. vesiculosus to a variety of strains (see Fig. $4 \mathrm{~b} ; \mathrm{n}=$ 9). Error bars are $95 \%$ CI. (b) Reproduction ( $\bullet$ ) and growth (ㅁ) of F. vesiculosus in Kiel Fjord (data courtesy of K. Maczassek and M. Hammann, IFMGEOMAR, Kiel, Germany). Reproduction data represent the mean percentage of fertile individuals in 4 populations, growth data represent the mean \% change per day of surface area as measured for 5 ind. in situ at $0.5 \mathrm{~m}$ depth $(\mathrm{n}=4)$; error bars are $\pm \mathrm{SD}$ for reproduction and $95 \% \mathrm{CI}$ for growth

Table 4. Effects of habitat depth on antimicrobial resistance strength. For each target species, activities were ranked across depths, then mean activity ranks per depths across all target species were calculated (1-way ANOVA and Tukey's HSD post hoc). Significant results are in bold

\begin{tabular}{|lccccc|}
\hline ANOVA & SS & df & MS & $F$ & $p$ \\
\hline Depth (m) & 43.5727 & 2 & 21.78634 & 4.41642 & $\mathbf{0 . 0 1 7 0 2 5}$ \\
Error & 251.5845 & 51 & 4.93303 & & \\
Tukey's & Depth & 1 & 2 & 3 \\
HSD & $(\mathrm{m})$ & & & \\
\hline 1 & 6 & & & $\mathbf{0 . 0 1 6 1 8 4}$ & 0.721277 \\
2 & 4 & $\mathbf{0 . 0 1 6 1 8 4}$ & & 0.100217 \\
3 & 1 & 0.721277 & 0.100217 & \\
\hline
\end{tabular}

It has been shown recently that Fucus vesiculosus bears a characteristic biofilm, the composition of which differs conspicuously from the biofilms of neighbouring macroalgae, from reference surfaces and from the colonizer pool in the surrounding seawater (Lachnit et al. 2009, 2010, present study). This is indicative of a selective recruitment of microbial foulers onto the alga. Such a process could be driven by strain-specific preferences for certain properties of the algal surface (wettability, surface free energy, exudates suitable as energy source, etc.) or by the strain-specific pro- or antifouling activities of algal surface metabolites. Once certain strains have established on the host alga they themselves may contribute to the modulation of further fouling.

While the biofilm on Fucus vesiculosus always differed significantly from other biofilms in the habitat, its composition was not constant but varied to some extent between thallus parts of a given individual, among individuals and among seasons (Lachnit et al. 2009). Additionally, the present study shows that both abiotic and biotic putative stressors affect abundance and/or composition of the biofilm. We consider a variable stressful when it leads to a reduction in some vital process of the alga such as growth, photosynthesis, reproduction or resistance. To date, stress effects on F. vesiculosus have been documented for light when radiation is below 15 to $30 \mu \mathrm{mol}$ $\mathrm{m}^{-2} \mathrm{~s}^{-1}$ (depending on the season), warming to beyond $20^{\circ} \mathrm{C}$, rapid temperature change, desiccation and osmotic stress, eutrophication, fouling and grazing (e.g. Bergström et al. 2003, Dethier et al. 2005, Middelboe et al. 2006, Korpinen et al. 2007a, Nygard \& Dring 2008, Rohde \& Wahl 2008a, Rohde et al. 2008, Pearson et al. 2009).

In the present study, all examined Fucus vesiculosus individuals carried a biofilm at their thallus surface. Freshly collected, healthy looking individuals usually had a sparse biofilm (ca. $5 \%$ cover). When exposed to various stressors, however, the density of the biofilm increased within 1 to $2 \mathrm{wk}$. Just maintaining algae in an aquarium with flow-through fjord water and natural sunlight resulted in a biofilm increase from 5 to $25 \%$ cover. Algae exposed to reduced (20\%) solar irradiance featured a biofilm cover of almost $60 \%$ and algae exposed to fluctuating and slightly warmer temperatures were almost entirely covered by bacteria (ca. $97 \%$ ). Our experiments with biofilms on inert substrata indicate that 


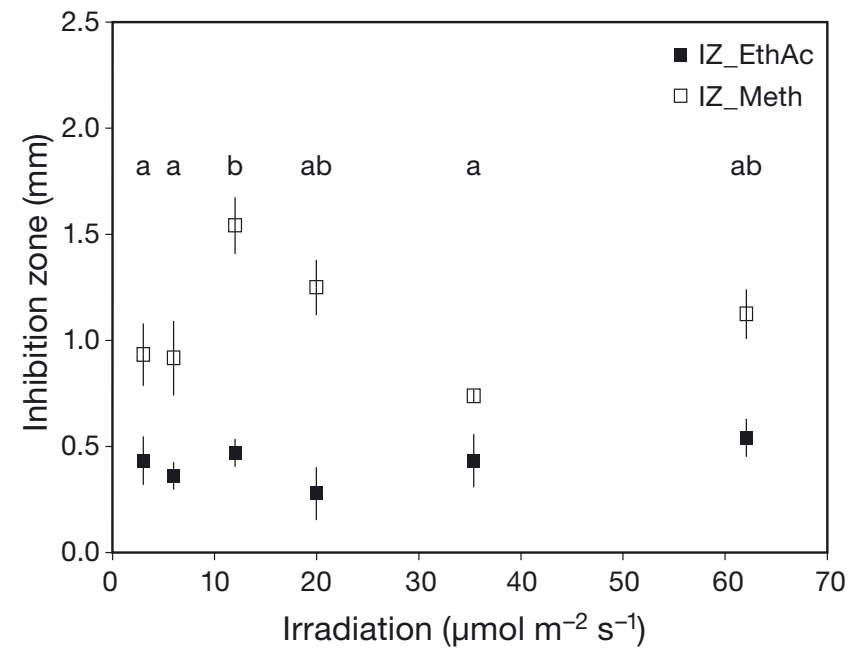

Fig. 6. Effects of light on resistance strength. Fucus vesiculosus exposed to different irradiation levels exhibited strongest antibiotic activity at relatively low light intensity in the polar extract, while the weaker activity of the non-polar extract was not affected by irradiation. IZ_EthAc: mean inhibition zone (distance to rim of paper disc in $\mathrm{mm}$ ) for the ethylacetate fraction; IZ_Meth: the same for the more polar methanol fraction. Methanol samples with different letters differed significantly $(\mathrm{n}=5)$. Error bars are $\pm \mathrm{SE}$ warming may directly enhance the formation of biofilms, while the shading effect is more likely due to changes in the host alga's surface properties. Under the 2 last stress treatments, the original alga-water interface was virtually replaced by a bacteria-water interface. Since the recognition of the alga by most interactors is bound to signals associated with its surface (colour, smell and taste; Wahl 2008), ecological consequences of dense microfouling can be expected. The shading effect of biofilms, which can be very substantial, as shown in the present study, should be particularly stressful when the increase of microfouling is caused by low light stress or when the fouled alga grows at depths with an irradiation close to its compensation point. The observed retreat of $F$. vesiculosus from deeper habitats in recent decades has usually been attributed to plankton blooms and macrofouling enhanced by eutrophication or other stressors (e.g. Schramm \& Nienhuis 1996, Korpinen et al. 2007b, Rohde et al. 2008). It could also be driven by epibiotic biofilms when the resistance of the alga is weakened and/or warmer temperatures intensify microfouling. Here we showed that unhindered microfouling may lead to substantial light reduction below the biofilm (Fig. 2a).
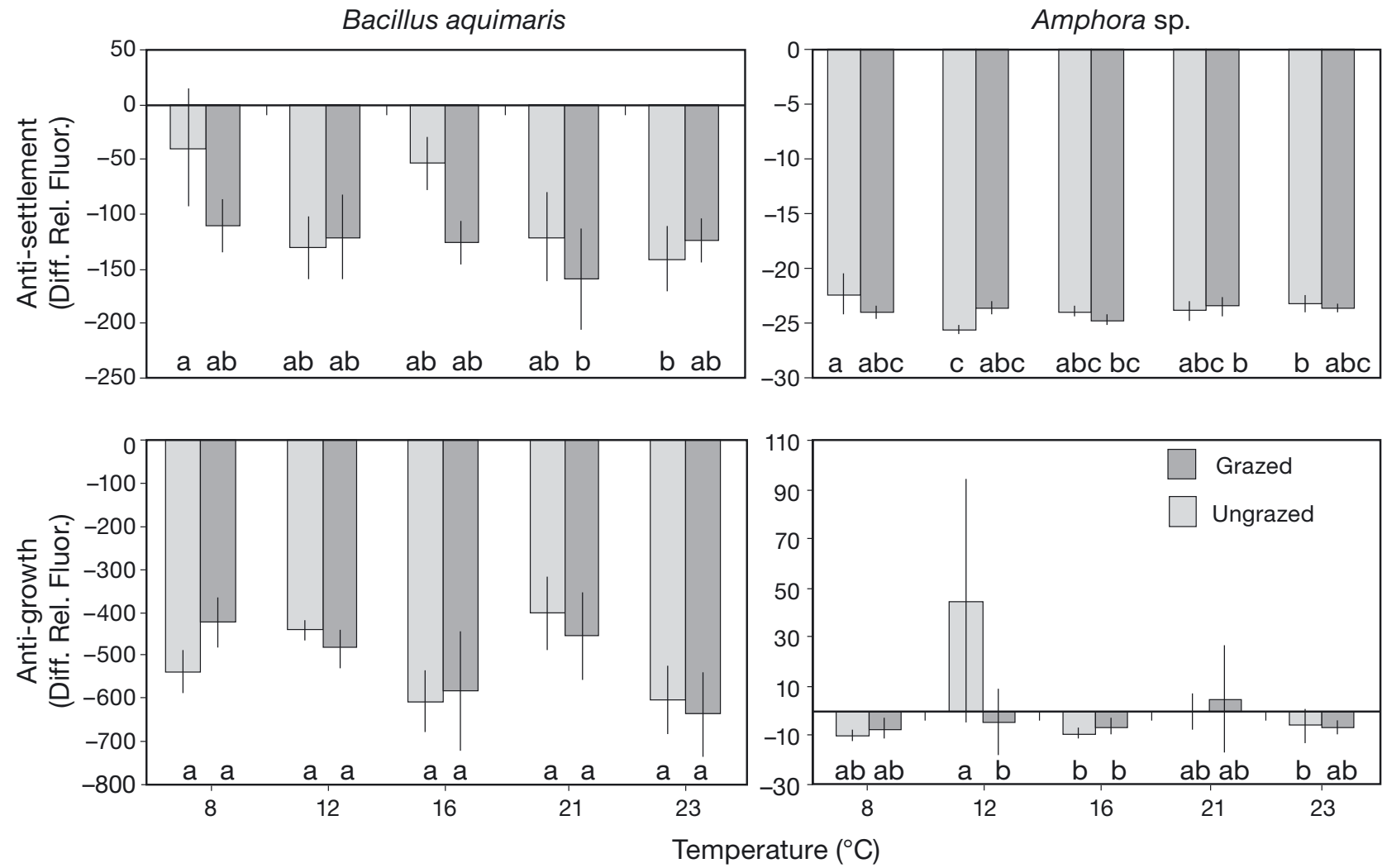

Fig. 7. Fucus vesiculosus exposed to different temperatures in the presence (dark grey bars) and absence (light grey bars) of grazers for $2 \mathrm{wk}$. Activity is expressed as the difference in relative fluorescence (Diff. Rel. Fluor.) $(\times 100)$ in wells with and without extract; inhibition produced negative values. Samples with different letters differed significantly $(\mathrm{n}=6)$. Error bars are $95 \% \mathrm{CI}$ 
The capacity of biofilms to modulate further fouling is well known (reviewed in Dobretsov et al. 2006b, Dobretsov 2008). When epibiotic biofilms favour macrofouling, the host may suffer a multitude of mostly negative effects such as increased drag, weight and shading (reviewed in Wahl 2008). Virtually unstudied, but probably important, are the effects of epibacteria on the recognition of the host by pathogens, parasites, symbionts and consumers.

The interaction of stressors may produce unexpected outcomes (Christensen et al. 2006, Darling \& Cote 2008). In the present study, shading under stressfully warm conditions led to a decrease instead of an increase in biofilm cover (Fig. 3b). The latter would have been expected, since fouling pressure increases with temperature (Fig. 2a). The density as well as the composition of biofilms may be affected differently by different presumptive stressors. Low light led to a reduction in epibiotic Cyanobacteria in favour of Gammaproteobacteria, while grazing by isopods increased the proportion of Bacteroidetes and decreased that of Cyanobacteria (Fig. 3c). Again, the 2 stressors interacted. The observed effect of grazers may be due to a variety of factors which are not mutually exclusive. The isopods may infect the prey algae with microbial strains which they carry on their carapaces or in their excrements, as described for snail-cordgrass interactions (Silliman \& Newell 2003). Their grazing activity may selectively favour or disfavour single epibiotic strains (e.g. selective grazing and metabolite release from wounded Fucus vesiculosus tissue). Their grazing activity may also alter various properties of the alga relevant for the biofilm (defense induction, exudate production, properties of the adhering boundary layer, etc.).

The observed effects of the tested abiotic or biotic environmental factors on quantity or quality of Fucus vesiculosus biofilms could represent direct reactions of the microbes to the variables and/or be the result of changes in the properties of the algal surface, e.g. the amount and/or nature of exuded metabolites. Warming enhances fouling pressure in inert surfaces (Fig. 2a) and also leads to an increase of epibiotic bacteria on Fucus vesiculosus under ample light but a significant decrease of epibiotic bacteria under low light (Table 2). Since microfouling pressure did not seem to be affected by light (Fig. 2b), the reversal of warming effects by shading could reflect a change in the algabiofilm interaction. While we do not know at this point which properties of the alga changed, one possible candidate could be its resistance to microfouling.

To quantify its resistance capacity, we extracted Fucus vesiculosus (most often only its surface) with organic solvents to harvest secondary metabolites which could account for pro-and antifouling effects and, thus, the abundance and composition of epibacteria. Commonly, 2 ways of harvesting resistance compounds are used: the complete extraction of the alga (usually after freeze-drying and grinding to a powder) and, more recently, surface extraction (e.g. de Nys et al. 1998). Both have their advantages and shortcomings. Surface extraction, when done correctly, only harvests the metabolites present at the algal surface and in the boundary layer adhering to this surface. However, the aufwuchs - mainly bacteria and some diatoms - may contribute to the chemical cocktail extracted. Their contribution depends on biofilm abundance (e.g. percent cover) and the metabolic activity of the microorganisms. We have shown that the abundance of epibacteria may vary from negligible to high. As no technique is available to date to separate the microorganisms from the algal surface without damaging the latter, surface extracts will always include an unknown proportion of microbial metabolites until the identity of compounds, and consequently their provenance, is known. Total extraction, conversely, will include metabolites from throughout the alga. Many of these will never reach the outer thallus surface and thus are irrelevant for microfouling. However, they are proportionately less contaminated by biofilm metabolites. Additionally, if resistance compounds are stored below the surface and only released 'on demand', they may be found in total but not surface extract during times when resistance is reduced. It is as yet unknown whether antimicrofouling resistance of $F$. vesiculosus can be regulated as shown for antifeeding resistance in the same species. A more practical advantage of total extraction is that it yields more material per algal individual, so that a better replication of bioassays becomes possible. The metabolite content of surface extracts is often so small that either replication is poor or algal individuals have to be pooled, which blurs phenotypic and genetic differences.

Using surface extracts in most experiments, we tested the chemical properties of the microhabitat in the boundary layer on the thallus surface which a potential fouler would encounter. We tested crude extracts and, to date, have little information about the chemical nature of the biologically active compounds. The chemical analysis is in progress and has so far shown that Fucus vesiculosus possesses more than 5 distinct microfouling-active compounds from a wide polarity range. The observation that activity strengths vary independently among $F$. vesiculosus individuals regarding response variables (growth and settlement) and target strains (Bacillus and Cytophaga) also hints at the existence of several independent bioactive compounds with differing impact. Phlorotannins, which are widely regarded as secondary metabolites with resistance potential (e.g. Pavia et al. 1999, Wikstroem 
\& Pavia 2004, Brock et al. 2007, Jormalainen \& Ramsay 2009), may be included. However, there is increasing evidence that their contribution to antifeeding or antifouling resistance was overestimated (e.g. Jennings \& Steinberg 1997, Toth \& Pavia 2002, Deal et al. 2003, Jormalainen et al. 2003, Kubanek et al. 2004, Yun et al. 2007). Reports on inhibitory activity of phlorotannins with regard to the proliferation of marine bacteria are rare (Lau \& Qian 1997, Iken et al. 2009), and we are unaware of any studies investigating how the biofilm formation on a thallus is affected by phlorotannins.

All Fucus vesiculosus individuals tested showed significant anti-settlement and/or anti-growth activity against most microbial strains tested. The extracts affected settlement and/or growth by factors ranging from 2 (attraction of Flavobacterium) to 0.03 (32-fold reduction of Bacillus growth; Fig. 4a,b). When evaluating the efficacy of these activities it should be taken into account that activity depends on concentration. We tested at natural concentrations, that is the mean concentration within the $30 \mu \mathrm{m}$ thick boundary layer. It is likely that within this layer a pronounced diffusive gradient exists with metabolite concentrations decreasing from the thallus surface outwards. In any case, the effect strengths found are substantial since the rates of settlement and growth are affected. This means that the differences in proportional abundance in a biofilm of unaffected, suppressed and favoured strains have the potential to increase exponentially over time.

The response of the target strains to the extracts varied among strains, between response variables (settlement versus growth, i.e. reproduction) and with the stress history of the alga. Growth proved more sensitive to the extracts than settlement (Fig. 4a). Possible reasons are that prior to the settlement counts, the microfoulers were exposed to the metabolites for only 1 to $3 \mathrm{~h}$, while in the growth assays they were exposed for 24 to $120 \mathrm{~h}$. Furthermore, growth of a bacterial population includes survival and reproduction and may thus depend on a larger number of potentially affected metabolic processes.

When comparing sensitivities among strains, Gammaproteobacteria seemed to be more sensitive than Bacteroidetes (Fig. 4b). Due to the low number of strains tested this is just a tendency. However, it matches well with the observation that on Fucus vesiculosus thalli Gammaproteobacteria are much rarer than Bacteroidetes, whereas we find the inverse proportion in the water column or on inert substrata (Lachnit et al. 2010). F. vesiculosus surface extracts seem to have the capacity to shape a particular biofilm by repelling or killing Gammaproteobacteria while not affecting or even attracting (see Flavobacterium sp.) Bacteroidetes. In the present study, the relation be- tween the sensitivity of bacterial taxa and their prevalence at the algal surface is merely correlative. A more mechanistic investigation into the modulation by algal metabolites of bacterial recruitment from the pelagic pool was recently carried out (Lachnit et al. 2009, 2010).

Resistance strength also fluctuated seasonally. It was strongest in March-April and weakest in July-August (Fig. 5a). This is in contrast to other findings where half of the investigated algal species did not show any seasonal pattern in antifouling resistance, while the remaining species seemed to be synchronized with water temperature (Hellio et al. 2004). A seasonal pattern in antifouling resistance strength could be resourcedriven, going down when energy is limited. Alternatively, such a pattern could be demand-driven, going up when fouling pressure increases or when the alga is most sensitive to fouling effects. Neither aspect has been investigated so far. During the seasonal period of strong resistance, light was already abundant and reproduction was intense, but growth had not yet reached its peak and fouling pressure was presumably low (Fig. 5b). In the summer phase of minimal resistance, growth was declining, reproduction was low, light was abundant (if not shaded by plankton blooms or epiphytes), microfouling probably intense because of the elevated water temperature, and temperature stress during emersion events could be extreme (up to $45^{\circ} \mathrm{C}$ air temperature). Whatever the factors driving the pattern, the effect seems to be that surfaces are best defended, probably cleanest and photosynthetically most efficient after a long period of light starvation, when reproduction is most intense and at the onset of the growth phase; in contrast, surfaces are least defended and presumably most fouled when irradiation is highest (and shading by a biofilm may even be protective at shallow depth) and when the growth period comes to an end. Autumn reproduction may rely on resources accumulated during the summer. Why long-term shading (winter) does not reduce resistance when short-term experimental shading did, cannot be explained to date. It should be noted, however, that Fucus vesiculosus can alleviate winter energy shortage due to substantial amounts of stored energy in the form of mannitol (Lehvo et al. 2001).

In contrast to antifeeding resistance ( $F$. Weinberger pers. obs.), the effects of temperature and grazing on the antimicrofouling resistance of Fucus vesiculosus were weak. Grazing did induce the production of antifeeding defenses in the same experiment and we had expected that this would somehow interact with antimicrofouling resistance. The 2 types of resistance may interact negatively when the 2 production processes compete for a limited resource. On the other hand, they may interact positively when the com- 
pounds produced in response to grazing are also active against fouling (e.g. Schmitt et al. 1995). The absence of any interaction suggests that the biochemical pathways and their products of the 2 forms of resistance are independent and/or resources were not limiting in this experiment.

All stress levels imposed in our experiments can be encountered in the natural habitat of Fucus vesiculosus and are occasionally far exceeded in nature. We chose to use moderate stress levels but apply them for a relatively extended period ( 2 to $3 \mathrm{wk}$ ) because the response time of $F$. vesiculosus to soft stress was found to be $14 \mathrm{~d}$ in some instances and because this constituted a natural scenario (Rohde \& Wahl 2008b). The finding that macro- and microfoulers may increase dramatically when $F$. vesiculosus is stressed (field observations and experiments presented here) is not entirely explained by the reported reaction of resistance to stress. Certain shading levels did impair antifouling resistance, but the response was not linear or steady, and the tested levels of temperature and grazing did not impair antifouling resistance. Other stressors or combinations thereof may affect the resistance capacity (suboptimal means or strong fluctuations of salinity, $\mathrm{pH}$, eutrophication and stagnation) and/or stress may directly affect the microfoulers.

We conclude that Fucus vesiculosus does chemically modulate the abundance and composition of its biofilm to some extent. This capacity is illustrated by the following findings. At a higher taxonomic level, the composition of biofilms on F. vesiculosus is characteristic and consistently differs from biofilms on neighbouring non-F. vesiculosus substrata or from the composition of the microbial colonizer pool in surrounding seawater (Lachnit et al. 2009, 2010). Metabolites from the F. vesiculosus surface affect settlement and proliferation of bacteria in a pattern consistent with the natural composition of F. vesiculosus biofilms, i.e. inhibited groups tend to be rare and favoured groups more abundant on F. vesiculosus (present study). Finally, the incorporation of F. vesiculosus metabolites in near-natural proportions into an inert matrix in situ recruits a biofilm from the natural colonizer pool which is more similar to the natural $F$. vesiculosus biofilm than to biofilms assembling on substrata exposed in parallel but without F. vesiculosus extracts (Lachnit et al. 2010). The strength of the modulation capacity varies seasonally, among target strains and among $F$. vesiculosus individuals. However, some fouling modulation capacity was found in all algal individuals examined and is thus never completely shut off. With respect to abundance and composition of F. vesiculosus biofilms, this modulating capacity of the host alga interacts with the effects of abiotic and biotic stressors in the environment. The chemical modulating capacity of $F$. vesiculosus itself is only weakly impacted by the stressors examined. An urgent question which should be investigated is whether F. vesiculosus (or other macroalgae) can regulate their antimicrofouling resistance 'on demand', i.e. in response to a variable fouling pressure or even to the identity of the fouler, in analogy to what has been shown for their antifeeding resistance.

Acknowledgements. We are most grateful to 3 anonymous referees whose thoughtful comments improved an earlier version of the manuscript substantially.

\section{LITERATURE CITED}

Amann R, Krumholz L, Stahl D (1990) Fluorescent oligonucleotide probing of whole cells for determinative, phylogenetic, and environmental studies in microbiology. J Bacteriol 1972:762-770

Armstrong E, Yan L, Boyd KG, Wright PC, Burgess JG (2001) The symbiotic role of marine microbes on living surfaces. Hydrobiologia 461:37-40

BACC Author Team (2008) Assessment of climate change for the Baltic Sea Basin. Springer, Heidelberg

> Bergström L, Berger R, Kautsky L (2003) Negative direct effects of nutrient enrichment on the establishment of Fucus vesiculosus in the Baltic Sea. Eur J Phycol 38:41-46

- Biermann CH, Schinner GO, Strathmann RR (1992) Influence of solar radiation, microalgal fouling, and current on deposition site and survival of embryos of a dorid nudibranch gastropod. Mar Ecol Prog Ser 86:205-215

Brock E, Nylund GM, Pavia H (2007) Chemical inhibition of barnacle larval settlement by the brown alga Fucus vesiculosus. Mar Ecol Prog Ser 337:165-174

Christensen MR, Graham MD, Vinebrooke RD, Findlay DL, Paterson MJ, Turner AM (2006) Multiple anthropogenic stressors cause ecological surprises in boreal lakes. Global Change Biol 12:2316-2322

Coleman A (1980) Enhanced detection of bacteria in natural environments by fluorochrome staining of DNA. Limnol Oceanogr 25:948-951

Darling ES, Cote IM (2008) Quantifying the evidence for ecological synergies. Ecol Lett 11:1278-1286

de Nys R, Dworjanyn SA, Steinberg PD (1998) A new method for determining surface concentrations of marine natural products on seaweeds. Mar Ecol Prog Ser 162:79-87

Deal MS, Hay ME, Wilson D, Fenical W (2003) Galactolipids rather than phlorotannins as herbivore deterrents in the brown seaweed Fucus vesiculosus. Oecologia 136:107-114

> Dethier MN, Williams SL (2009) Seasonal stresses shift optimal intertidal algal habitats. Mar Biol 156:555-567

$>$ Dethier MN, Williams SL, Freeman A (2005) Seaweeds under stress: manipulated stress and herbivory affect critical lifehistory functions. Ecol Monogr 75:403-418

Dobretsov S (2008) Inhibition and induction of marine biofouling by biofilms. In: Flemming HC, Murthy PS, Venkatesan $\mathrm{R}$, Cooksey $\mathrm{K}$ (eds) Marine and industrial biofouling, Vol 4. Springer, Heidelberg, p 293-314

> Dobretsov S, Dahms HU, Harder T, Qian PY (2006a) Allelochemical defense against epibiosis in the macroalga Caulerpa racemosa var. turbinata. Mar Ecol Prog Ser 318: 165-175

> Dobretsov S, Dahms HU, Qian PY (2006b) Inhibition of biofouling by marine microorganisms and their metabolites. Biofouling 22:43-54 
Eden PA, Schmidt TM, Blakemore RP, Pace NR (1991) Phylogenetic analysis of Aquaspirillum magnetotacticum using polymerase chain reaction-amplified 16S rRNA-specific DNA. Int J Syst Bacteriol 41:324-325

Enderlein P, Moorthi S, Rohrscheidt H, Wahl M (2003) Optimal foraging versus shared doom effects: interactive influence of mussel size and epibiosis on predator preference. J Exp Mar Biol Ecol 292:231-242

Ericcson LE, Lewis L (1953) On the occurrence of vitamin B12 factors in marine algae. Ark Kemi 6:427-442

Fries L (1982) Selenium stimulates growth of marine macroalgae in axenic culture. J Phycol 18:328-331

Harder T (2008) Marine epibiosis: concepts, ecological consequences and host defence. In: Flemming HC, Murthy PS, Venkatesan R, Cooksey K (eds) Marine and industrial biofouling, Vol 4. Springer, Heidelberg, p 219-231

Harvell CD (1998) Genetic variation and polymorphism in the inducible spines of a marine bryozoan. Evolution 52:80-86

Hellio C, Marechal JP, Veron B, Bremer G, Clare AS, Le Gal Y (2004) Seasonal variation of antifouling activities of marine algae from the Brittany coast (France). Mar Biotechnol 6: 67-82

> Holmstrom C, Kjelleberg S (1999) Marine Pseudoalteromonas species are associated with higher organisms and produce biologically active extracellular agents. FEMS Microbiol Ecol 30:285-293

Iken K, Amsler CD, Amsler MO, McClintock JB, Baker BJ (2009) Field studies on deterrent properties of phlorotannins in Antarctic brown algae. Bot Mar 52:547-557

IPCC (2007) Climate Change 2007: Synthesis Report. Contribution of Working Groups I, II and III to the Fourth Assessment Report of the Intergovernmental Panel on Climate Change (Core Writing Team, Pachauri RK, Reisinger A [eds]) IPCC, Geneva

Jennings JG, Steinberg PD (1997) Phlorotannins versus other factors affecting epiphyte abundance on the kelp Ecklonia radiata. Oecologia 109:461-473

Jormalainen V, Ramsay T (2009) Resistance of the brown alga Fucus vesiculosus to herbivory. Oikos 118:713-722

> Jormalainen V, Honkanen T, Koivikko R, Eranen J (2003) Induction of phlorotannin production in a brown alga: Defense or resource dynamics? Oikos 103:640-650

Jormalainen V, Wikstrom SA, Honkanen T (2008) Fouling mediates grazing: intertwining of resistances to multiple enemies in the brown alga Fucus vesiculosus. Oecologia 155:559-569

Korpinen S, Honkanen T, Vesakoski O, Hemmi A, Koivikko R, Loponen J, Jormalainen V (2007a) Macroalgal communities face the challenge of changing biotic interactions: review with focus on the Baltic Sea. Ambio 36:203-211

Korpinen S, Jormalainen V, Honkanen T (2007b) Effects of nutrients, herbivory, and depth on the macroalgal community in the rocky sublittoral. Ecology 88:839-852

Krause-Jensen D, Carstensen J, Dahl K, Back S, Neuvonen S (2009) Testing relationships between macroalgal cover and Secchi depth in the Baltic Sea. Ecol Indic 9: 1284-1287

Kubanek J, Lester SE, Fenical W, Hay ME (2004) Ambiguous role of phlorotannins as chemical defenses in the brown alga Fucus vesiculosus. Mar Ecol Prog Ser 277:79-93

Lachnit T, Blumel M, Imhoff JF, Wahl M (2009) Specific epibacterial communities on macroalgae: phylogeny matters more than habitat. Aquat Biol 5:181-186

> Lachnit T, Wahl M, Harder T (2010) Isolated thallus-associated compounds from the macroalga Fucus vesiculosus mediate bacterial surface colonization in the field similar to that on the natural alga. Biofouling 26:247-255
Lau SCK, Qian PY (1997) Phlorotannins and related compounds as larval settlement inhibitors of the tube-building polychaete Hydroides elegans. Mar Ecol Prog Ser 159: 219-227

> Lee OO, Lau SCK, Qian PY (2006) Defense against epibiosis in the sponge Mycale adhaerens: modulating the bacterial community associated with its surface. Aquat Microb Ecol 43:55-65

Lehvo A, Back S, Kiirikki M (2001) Growth of Fucus vesiculosus L. (Phaeophyta) in the northern Baltic proper: energy and nitrogen storage in seasonal environment. Bot Mar 44: 345-350

Matsuo Y, Imagawa H, Nishizawa M, Shizuri Y (2005) Isolation of an algal morphogenesis inducer from a marine bacterium. Science 307:1598

> Middelboe AL, Sand-Jensen K, Binzer T (2006) Highly predictable photosynthetic production in natural macroalgal communities from incoming and absorbed light. Oecologia 150:464-476

> Nygard CA, Dring MJ (2008) Influence of salinity, temperature, dissolved inorganic carbon and nutrient concentration on the photosynthesis and growth of Fucus vesiculosus from the Baltic and Irish Seas. Eur J Phycol 43:253-262

Paul VJ, Ritson-Williams R (2008) Marine chemical ecology. Nat Prod Rep 25:662-695

Pavia H, Cervin G, Lindgren A, Åberg P (1997) Effects of UV-B radiation and simulated herbivory on phlorotannins in the brown alga Ascophyllum nodosum. Mar Ecol Prog Ser 157: 139-146

Pavia H, Toth G, Åberg P (1999) Trade-offs between phlorotannin production and annual growth in natural populations of the brown seaweed Ascophyllum nodosum. J Ecol 87:761-771

> Pearson GA, Lago-Leston A, Mota C (2009) Frayed at the edges: selective pressure and adaptive response to abiotic stressors are mismatched in low diversity edge populations. J Ecol 97:450-462

Penhale PA (1977) Macrophyte-epiphyte biomass and productivity in an eelgrass (Zostera marina L.) community. J Exp Mar Biol Ecol 26:211-224

Railkin AI (2004) Marine biofouling: colonization processes and defenses. CRC Press, Boca Raton, FL

Richmond CA, Seed R (1991) A review of marine macrofouling communities with special reference to animal fouling. Biofouling 3:151-168

> Rohde S, Wahl M (2008a) Antifeeding defense in Baltic macroalgae: induction by direct grazing versus waterborne cues. J Phycol 44:85-90

Rohde S, Wahl M (2008b) Temporal dynamics of induced resistance in a marine macroalga: time lag of induction and reduction in Fucus vesiculosus. J Exp Mar Biol Ecol 367:227-229

Rohde S, Molis M, Wahl M (2004) Regulation of anti-herbivore defence by Fucus vesiculosus in response to various cues. J Ecol 92(6):1011-1018

Rohde S, Hiebenthal C, Wahl M, Karez R, Bischof K (2008) Decreased depth distribution of Fucus vesiculosus (Phaeophyceae) in the Western Baltic: effects of light deficiency and epibionts on growth and photosynthesis. Eur J Phycol 43:143-150

> Schmitt TM, Hay ME, Lindquist N (1995) Constraints on chemically mediated coevolution: multiple functions for seaweed secondary metabolites. Ecology 76:107-123

Schramm W, Nienhuis PH (1996) Marine benthic vegetation: recent changes and the effects of eutrophication. Springer, Berlin

Silliman BR, Newell SY (2003) Fungal farming in a snail. Proc 
Natl Acad Sci USA 100:15643-15648

Tollrian R, Harvell CD (1999) The evolution of inducible defenses. In: Tollrian R, Harvell CD (eds) The ecology and evolution of inducible defenses. Princeton University Press, Princeton, NJ, p 306-321

Toth GB, Pavia H (2002) Lack of phlorotannin induction in the kelp Laminaria hyperborea in response to grazing by two gastropod herbivores. Mar Biol 140:403-409

Underwood A (1997) Experiments in ecology. Cambridge University Press, Cambridge

> Vinebrooke RD, Cottingham KL, Norberg J, Scheffer M, Dodson SI, Maberly SC, Sommer U (2004) Impacts of multiple stressors on biodiversity and ecosystem functioning: the role of species co-tolerance. Oikos 104:451-457

Vogt H, Schramm W (1991) Conspicuous decline of Fucus in Kiel Bay (Western Baltic): what are the causes? Mar Ecol Prog Ser 69:189-194

Wahl M (2008) Ecological lever and interface ecology: epibiosis modulates the interactions between host and environment. Biofouling 24:427-438

Wahl M, Hay ME (1995) Associational resistance and shared doom: effects of epibiosis on herbivory. Oecologia 102:

Editorial responsibility: Matthias Seaman,

Oldendorf/Luhe, Germany
$329-340$

> Wahl M, Kroger K, Lenz M (1998) Non-toxic protection against epibiosis. Biofouling 12:205-226

> Wahl M, Molis M, Davis A, Dobretsov S and others (2004) UV effects that come and go: a global comparison of marine benthic community level impacts. Global Change Biol 10: 1962-1972

Wakefield R, Murray S (1998) Factors influencing food choice by the seaweed-eating marine snail Norrisia norrisi (Trochidae). Mar Biol 130:631-642

Weinberger F, Buchholz B, Karez R, Wahl M (2008) The invasive red alga Gracilaria vermiculophylla in the Baltic Sea: adaptation to brackish water may compensate for light limitation. Aquat Biol 3:251-264

Wikstroem SA, Pavia H (2004) Chemical settlement inhibition versus post-settlement mortality as an explanation for differential fouling of two congeneric seaweeds. Oecologia 138:223-230

Yun HY, Cruz J, Treitschke M, Wahl M, Molis M (2007) Testing for the induction of anti-herbivory defences in four Portuguese macroalgae by direct and water-borne cues of grazing amphipods. Helgol Mar Res 61:203-209

Submitted: August 24, 2009; Accepted: April 28, 2010

Proofs received from author(s): July 9, 2010 